\author{
BULETINUL INSTITUTULUI POLITEHNIC DIN IAŞI \\ Publicat de \\ Universitatea Tehnică „Gheorghe Asachi” din Iaşi \\ Volumul 67(71), Numărul 1, 2021 \\ Secţia \\ CONSTRUCTII. ARHITECTURĂ \\ DOI: $10.2478 /$ bipca-2021-0005 \\ sciendo
}

\title{
ASSESSING THE LEVEL OF CONCRETE HARDENING BY THE MATURITY METHOD
}

BY

\section{PAMFIL ALEXANDRA*}

\author{
„Gheorghe Asachi” Technical University of Iaşi, Faculty of Civil Engineering and Building \\ Services, Iasi, Romania
}

Received: January 28, 2021

Accepted for publication: March 21, 2021

Abstract Curing levels under standardized temperature and humidity conditions of concrete (but also for medium temperature conditions in the range of $+5^{\circ} \mathrm{C} \rightarrow+35^{\circ}$ $\mathrm{C}$, maximum $+40^{\circ} \mathrm{C}$, depending on the type of cement used in the preparation of concrete, in order not to record final resistance losses) can be plotted graphically with a single chart for all concrete grades prepared with the same type of cement at different ages.

Each concrete hardening diagram corresponds to a degree of maturation, defined as the area between the average temperature plot of the concrete and the $-10^{\circ} \mathrm{C}$ order, over time, so that only resistance based on the temperature measurement during the curing can be evaluated (or the level of hardening) of the concrete necessary for the technological process - decofing, precompression force transfer, acceptance of freezing of the concrete without adverse effects, precast concrete transport etc., but also the necessary times for starting a technological process. cement.

Keywords: level of hardening, degree of maturation, unitary cement, composite

*Corresponding author; e-mail: alexandra.pamfil1@gmail.com (C) 2021 Pamfil Alexandra

This is an open access article licensed under the Creative Commons Attribution-NonCommercialNoDerivatives 4.0 International License (CC BY-NC-ND 4.0). 


\section{Introduction}

The conventional reinforced concrete stage corresponds to the age of 28 days of concrete curing under standardized conditions. The concrete is kept in standardized patterns, in shape and size, at average curing temperature, humidity of $100 \%$ to 7 days (in the first 24 hours, preservation in patterns and then up to 7 days, decoupled specimens), and humidity $60 \%$ within the next 21 days.

The conventional reinforced concrete stage is defined by the degree of maturation $\left(\mathrm{h}{ }^{\circ} \mathrm{C}\right)$, which is the area between the average temperature, and the order of $-10^{\circ} \mathrm{C}$, for the duration of 28 days x 24 hours / day, Fig. 1.

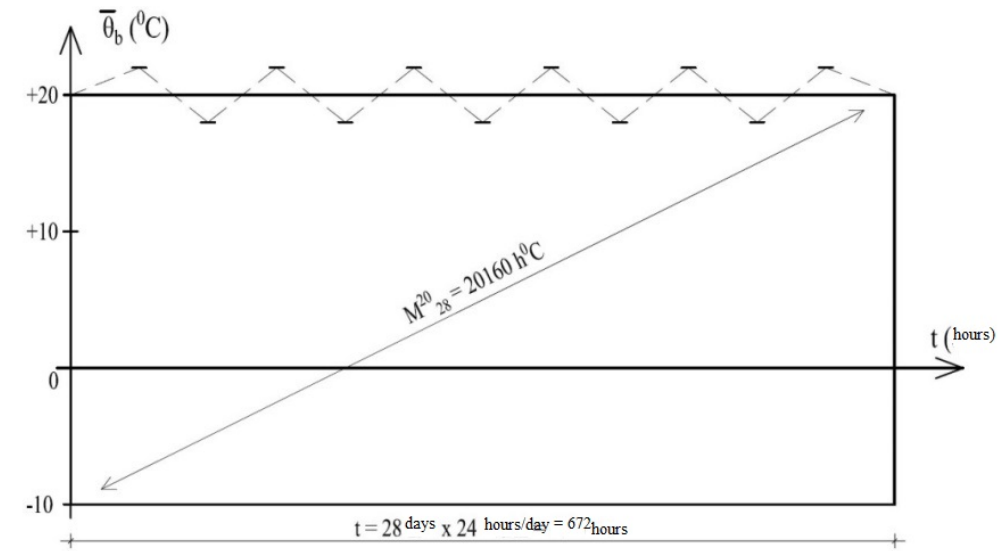

Fig. 1 - Maturation degree of Portland cement [9]

$$
M_{28}^{20}=\left(\theta_{\text {bmed }}+10\right) \cdot 28 \cdot 24=20160 h^{\circ} C
$$

The definition of the quality of the reinforced concrete and the reinforced concrete stage $\bar{R}_{28}^{20}$, is made by the compressive strength determined on specimens executed, preserved and tested under standardized conditions. An example of evolution of compressive strength of concrete is shown in Fig. 2. In practice, using these diagrams is difficult because there is a chart for each concrete and cement type (slow, normal, fast) used to make the concrete. The compressive strength defines all other mechanical performance of the concrete, as a percentage of the compressive strength $\bar{R}_{28}^{20}$.

In the technological process of their realization, the concrete building elements are subjected to efforts before reaching the mechanical resistances that characterize the conventional stage of reinforced concrete. For example: technological processes of decofing, transfer of precompression force, natural 
freeze-thaw process, technological processes of decofing, transportation and storage of precast concrete elements, etc. Therefore, it is necessary to know the level of hardening at any time before reaching the level of cure corresponding to the conventional reinforced concrete stage. The concrete hardening level $(\beta)$ is defined as the percentage ratio between the average compressive strength at a given time $\bar{R}_{\beta}^{20}$, and the average compressive strength $\bar{R}_{28}^{20}$ corresponding to the conventional reinforced concrete stage.

$$
\beta=\frac{\bar{R}_{\beta}^{20}}{\bar{R}_{28}^{20}} \cdot 100 \%
$$

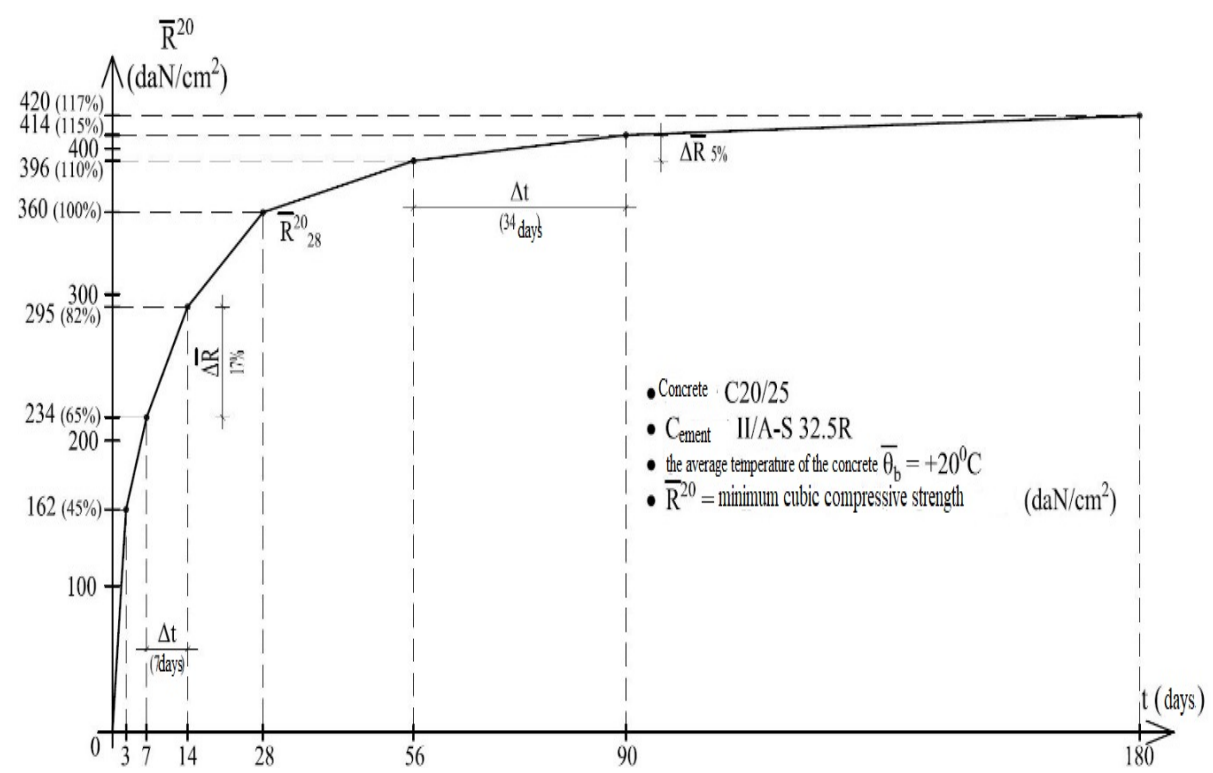

Fig. 2. - The evolution in time of the minimum cube compressive strength of concrete

Curing levels under standardized temperature and humidity conditions of concrete can express graphically with a single diagram for all concrete grades prepared with the same type of cement at different ages, Fig. 3.

The $20160 h^{0} C$ value of the maturity level $M_{28}^{20}$ of a concrete corresponds to the average compressive strength value $\bar{R}_{28}^{20}$, which characterizes the conventional reinforced concrete stage. For the same standardized curing conditions, at times 
$t_{i}=t_{\beta}<28$ days $\mathrm{x} 24$ hours $/$ day $=672$ hours, there is a direct correlation between the partial cure level $\beta$ and degree of maturation $M_{\beta}^{20}$ :

$$
M_{\beta}^{20}=\left(\bar{\theta}_{b}+10\right) \cdot t_{\beta}
$$

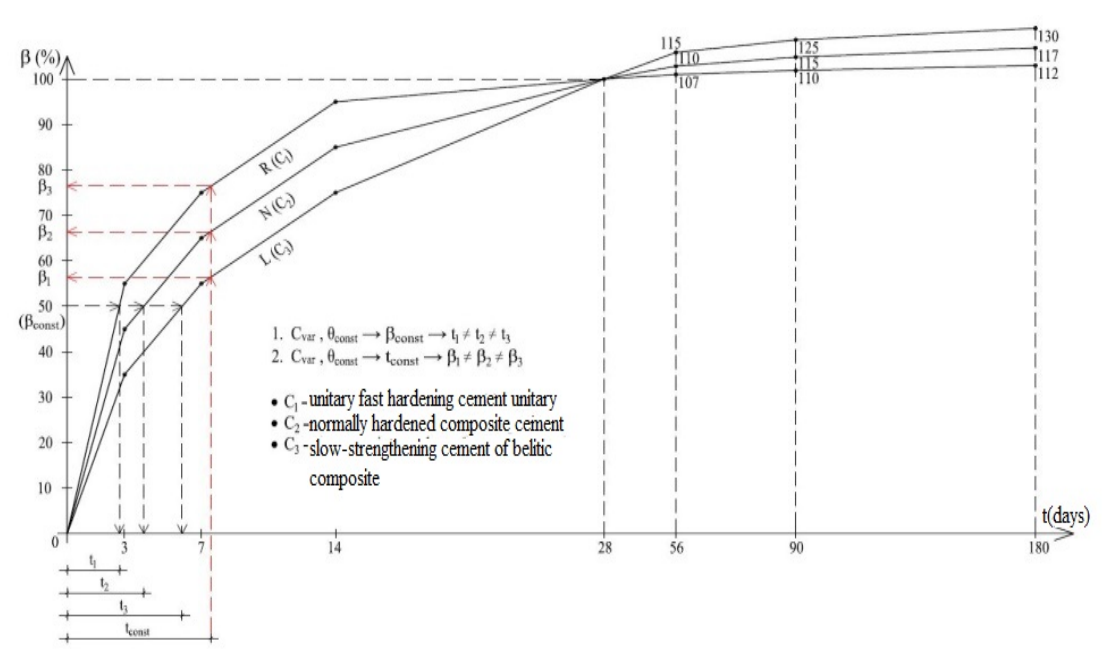

Fig. 3 Concrete cure charts under standardized temperature and humidity conditions, expressed as hardening level

The correlation $\beta \Leftrightarrow M_{\beta}^{20}$ is presented in Table 1 and Fig. 4 .

\section{Table 1}

Correlation $\beta \Leftrightarrow M_{\beta}^{20}\left(h^{\circ} C\right)$, for concrete prepared with different cements [9]

\begin{tabular}{|c|c|c|c|c|c|c|c||}
\hline \multirow{2}{*}{$\begin{array}{c}\text { Type of } \\
\text { concrete }\end{array}$} & \multicolumn{6}{|c||}{ Degree of maturation $M_{\beta}^{20}\left(h^{\circ} C\right)$, for $\beta=(\%)$} \\
\cline { 2 - 8 } & 10 & 30 & 50 & 60 & 70 & 90 & 100 \\
\hline II/B-S 32,5 & 660 & 1620 & 3980 & 6240 & 9790 & 16130 & 20160 \\
\hline II/A-S 32,5 R & 600 & 1290 & 2760 & 4050 & 5930 & 14560 & 20160 \\
\hline I 42,4 & 520 & 1150 & 2510 & 3720 & 5520 & 10080 & 20160 \\
\hline
\end{tabular}


From the diagrams of Fig. 4 we can determine the actual concrete curing time $t_{i}$ corresponding to a level of cure $\beta_{\text {nec }}$ needed to carry out a technological process, or determine the actual curing levels $\beta_{i}$ corresponding to a term $t_{n e c}$ that characterizes a technological process that takes place at an average temperature of $+20^{\circ} \mathrm{C}$. The diagrams can be used, reading as follows:

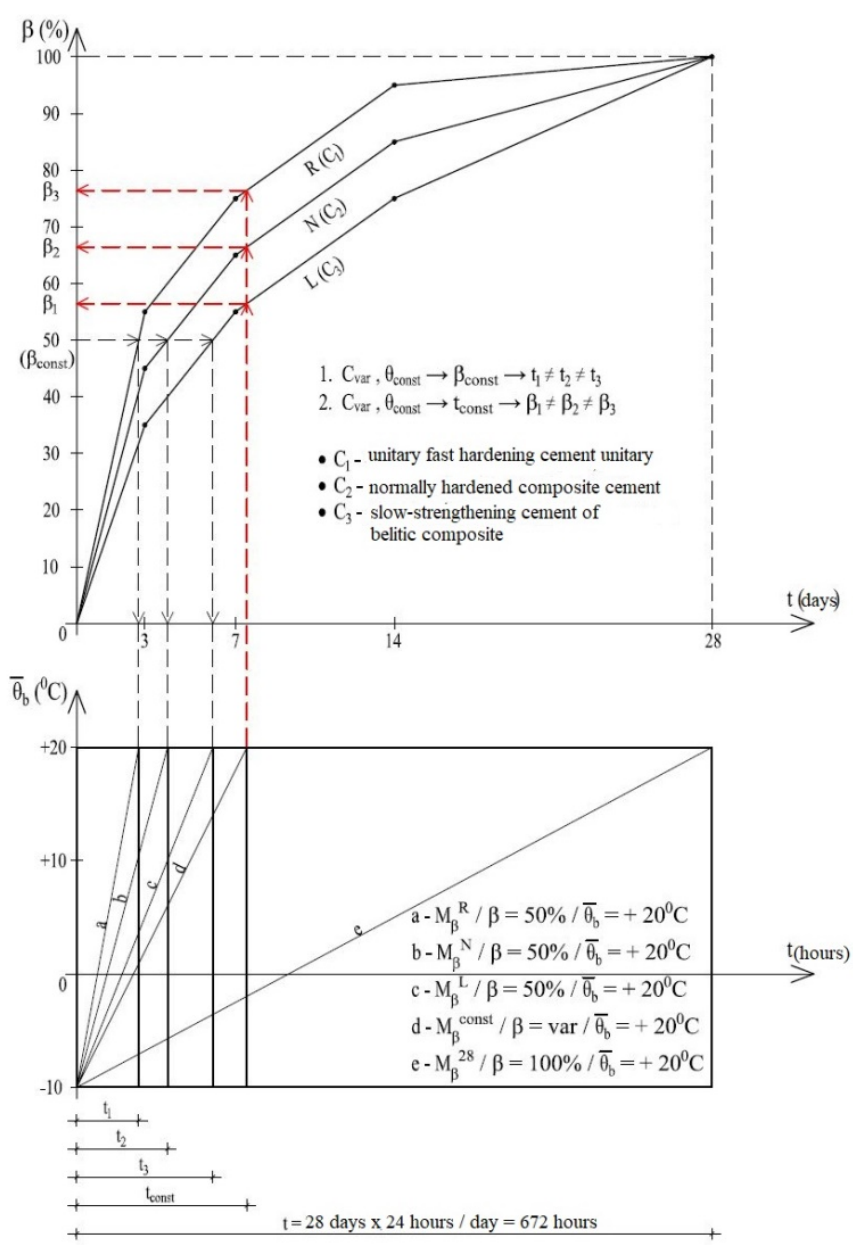

Fig. 4 - Correlation of cure level $\beta$ with maturity $M_{\beta}^{20}$

$$
\left\{\begin{array} { l } 
{ \overline { \theta } _ { b } = \text { const. } } \\
{ C _ { i } = \text { dif. } }
\end{array} \text { for } \beta _ { \text { nec } } \Rightarrow t _ { 1 } \neq t _ { 2 } \neq t _ { 3 } \text { or } \left\{\begin{array}{l}
\bar{\theta}_{b}=\text { const. } \\
C_{i}=\text { dif. }
\end{array} \text { for } t_{\text {nec }} \Rightarrow \beta_{1} \neq \beta_{2} \neq \beta_{3}\right.\right.
$$


In the day-to-day reality, the average temperature of the concrete environment, concrete aftertreatment, and especially concrete hardening differ from the standard $+20^{\circ} \mathrm{C}$ standard temperature. Therefore, it is important to be able to assess cement concrete hardening levels for curing conditions at temperatures other than $+20^{\circ} \mathrm{C}$. The technical literature [4], [7], [9] presents the concept of maturing of the concrete for the average temperature range $+5{ }^{\circ} \mathrm{C} \div$ $+35^{\circ} \mathrm{C}$ (maximum $+40^{\circ} \mathrm{C}$ ). In this temperature range, the curing of the concrete prepared with any type of Portland cement is ensured, without any final decrease in the compressive strength, even if the cure speed and the amount of heat emitted by the exotherm of the cement are different [9] [11].

The maximum admissible temperatures of Portland cement prepared in order to avoid any final loss of resistance are: $\theta_{b}^{*} \leq+35^{\circ} C$ for Portland cement units, without added (Type I 32,5R, I 42,5R, I 52,5R - SR 388 / 1995) and for composite Portland cements with additions to their manufacture (type II / A-S (-M, -V, -P, L) $32,5 \mathrm{R}, 42,5 \mathrm{R}, 52,5 \mathrm{R}$, IVA, SR II / AS, SR II / AP, 32,5, 42,5, 52,5 - SR 3011/1996) [4], [7], [9], [10]. Curing levels under different temperature conditions than standardized concrete curing conditions can be plotted on a single chart for all concrete grades prepared with the same type of cement and for an average curing temperature in the range of $+5{ }^{\circ} \mathrm{C} \rightarrow+35^{\circ} \mathrm{C}\left(\max .+40{ }^{\circ} \mathrm{C}\right)$, Fig. 5.

There is proportionality between $M_{\beta}^{20}$ and $M_{\beta}^{\theta}$ [4], [7], [9] for the average temperature range: $0^{\circ} C\left(+5^{\circ} C\right) \leq \theta_{b} \leq \theta_{b}^{*}=+35^{\circ} C\left(+40^{\circ} C\right)$

$M_{\beta}^{20}=\left(\bar{\theta}_{b}+10\right) \cdot t_{i}\left(h^{o} C\right), \bar{\theta}_{b}=+20^{\circ} C(3)$ and $M_{\beta}^{\theta}=\left(\bar{\theta}_{i}+10\right) \cdot t_{i} \cdot k_{\theta i}\left(h^{o} C\right)$, $\overline{\theta_{i}} \neq+20^{\circ} C$

Correlations $\theta \Leftrightarrow M_{\beta}^{\theta}$ are presented in Table 2 


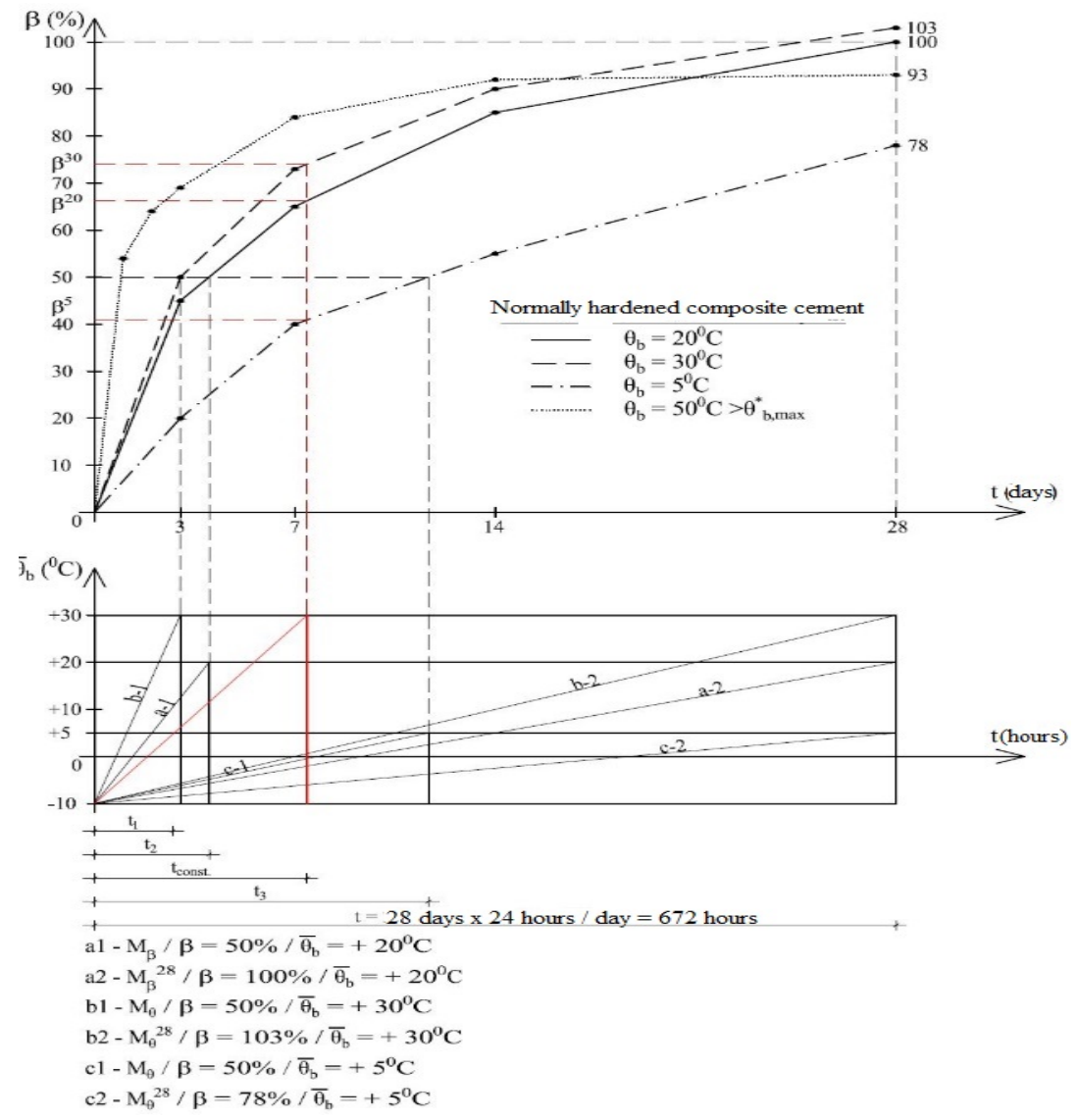

Fig. 5 - Concrete cure charts under temperature conditions other than standardized conditions (time chart - hardening level - maturation degree) [3]

Table 2

$\theta \leftrightarrow M_{\theta}$ correlation; the values of parameter $m_{i}=\left(\theta_{i}+10\right) \cdot k_{\theta i}[7],[9]$

\begin{tabular}{||c|c|c|c|c|c|c|c|c|c|c||}
\hline $\begin{array}{c}\theta_{i} \\
\left({ }^{\circ} \mathrm{C}\right)\end{array}$ & 1 & 5 & 10 & 15 & 20 & 30 & 35 & 40 & 50 & 60 \\
\hline \hline $\begin{array}{c}m_{i} \\
\left({ }^{\circ} \mathrm{C}\right)\end{array}$ & 3 & 11 & 19 & 24 & 30 & 47 & 61 & 80 & 134 & 212 \\
\hline$k_{\theta i}$ & 0,27 & 0,73 & 0,95 & 0,96 & 1,00 & 1,18 & 1,36 & 1,60 & 2,23 & 3.03 \\
\hline
\end{tabular}


From the diagrams of Fig. 5 it is possible to determine the actual concrete curing times $t_{i}$ corresponding to a level of hardening $\beta_{\text {nec }}^{\theta}$, necessary for carrying out a technological process or to determine the actual curing levels $\beta_{i}^{\theta}$ corresponding to a term $t_{n e c}$ that characterizes a process that would be carried out at an average temperature of the environment different from $+20^{\circ} \mathrm{C}$.

The diagrams can be used, reading as follows:

$$
\begin{aligned}
& \left\{\begin{array} { l } 
{ \overline { \theta } _ { i } \neq + 2 0 ^ { \circ } C } \\
{ C = \text { const. } }
\end{array} \text { for } \quad \beta _ { \text { nec } } ^ { \theta } \Rightarrow t _ { 1 } \neq t _ { 2 } \neq t _ { 3 } \quad \text { or } \quad \left\{\begin{array}{l}
\bar{\theta}_{i} \neq+20^{\circ} C \\
C_{i}=\text { const. }
\end{array}\right.\right. \text { for } \\
& t_{\text {nec }} \Rightarrow \beta_{1}^{\theta} \neq \beta_{2}^{\theta} \neq \beta_{3}^{\theta} \\
& \text { If } \theta_{b}>\theta_{b}^{*} \text { for example } \theta \mathrm{b}=+50^{\circ} \mathrm{C} \text { ), at } 28 \text { days, final resistance drops }
\end{aligned}
$$
of $7.0 \%$ are found in the cements prepared with cements having a normal cure rate; final strength decreases can reach $24 \%$ for cement-based concrete having a fast cure rate [9].

In conclusion, it is only on the basis of measuring the temperature of the concrete during its curing that, at different time intervals, maturation degrees corresponding to the time elapsed and the average temperature over that time interval can be determined; the maturity degrees determined indicate the concrete hardening levels, including the corresponding compressive strength.

\section{Conclusions}

In conclusion, it is only on the basis of measuring the temperature of the concrete during its curing that, at different time intervals, maturation degrees corresponding to the time elapsed and the average temperature over that time interval can be determined; the maturity degrees determined indicate the concrete hardening levels, including the corresponding compressive strength

Conclusions must be concise and present the main ideas resulting from the experiment. Future directions of research can be mentioned.

\section{REFERENCES}

* Code of practice for the execution of works in concrete, reinforced concrete and prestressed concrete, indicative NE 012-99, MLPAT, Bucharest, 1999;

** Code of practice for the execution of works in concrete, reinforced concrete and precompacted concrete. Part 1: Concrete production, indicative NE 012-1: 2007, Part 2: Execution of concrete works, indicative NE 012/2: 2010, Bucharest, 2007; 2010; 
* Testing on concrete. Tests on reinforced concrete. Determination of mechanical strengths. STAS 1275-88, Bucharest, 1988;

* Testing on hardened concrete. Part I Form, dimensions and other conditions for specimens and patterns, SR EN 12390-1: 2013;

Degeimbre, R., Technologie des betons; Notes de cours provisoires, Liege, 1999;

Dreux, Georges, Nouveau guide du béton, ed. Eyrolles, Paris, 1979 and 1998.

Ionescu, I., Ispas, T., Concrete Properties and Technology, Ed. Bucharest, 1997;

Moldovan, V., Additives in Concrete Technical Ed., Bucharest, 1978;

Neville, A., M., Concrete Properties, Technical Publishing House, Bucharest, 1979;

Trelea, A., Giuşcă, N., Pamfil, E., Technology and mechanization of construction works, vol. 2, I P Iaşi, 1988;

\section{EVALUAREA NIVELULUI DE ÎNTĂRIRE A BETONULUI PRIN METODAGRADULUI DE MATURIZARE}

\section{(Rezumat)}

Nivelele de întărire în condiţii standardizate de temperatură și umiditate a betonului (dar și pentru condiții de temperaturi medii cuprinse în intervalul $+5^{\circ} \mathrm{C} \rightarrow+35$ ${ }^{\circ} \mathrm{C}$, maximum $+40{ }^{\circ} \mathrm{C}$, în funcție de tipul cimentului utilizat la prepararea betonului, pentru a nu se înregistra pierderi finale de rezistență) se pot exprima grafic cu o singură diagramă pentru toate clasele de beton preparate cu acelaşi tip de ciment, la diferite vârste.

Fiecărei diagrame de întărire a betonului îi corespunde un grad de maturizare, definit ca suprafața cuprinsă între diagrama de temperatură medie a betonului și ordonata de $-10{ }^{\circ} \mathrm{C}$, în timp, astfel încât, doar pe baza măsurării temperaturii din timpul întăririi să se poată evalua rezistența (sau nivelul de întărire) a betonului necesară pentru proces tehnologic - decofrare, transfer forță de precomprimare, acceptarea înghețării betonului fără efecte defavorabile, transport prefabricate din beton etc., dar și timpii necesari începerii desfășurării unui proces tehnologic. 